\title{
Growing-season microclimate variability within an old-growth Douglas-fir forest
}

\author{
Jiquan Chen ${ }^{1, *}$, Jerry F. Franklin ${ }^{2}$ \\ 'School of Forestry and Wood Products, Michigan Technological University, Houghton, Michigan 49931, USA \\ ${ }^{2}$ College of Forest Resources, University of Washington, Seattle, Washington, USA
}

\begin{abstract}
Physical properties of old-growth Douglas-fir [Pseudotsuga menziesii (Mirb.) Frankco] forests in the west coast regions of North America have received very little attention aver 30 yr of extensive research. This study was aimed at characterizing the forest microclimate and its variability over the growing season (June to October). Three $200 \mathrm{~m}$ line transects in the interior area of an old-growth Douglas-fir forest of the Wind River Experimental Forest, Gifford Pichot National Forest, Washington, USA, were used to install randomly 8 automatic-recording systems to quantify growing-season microclimate and variability in 1990 and 1992, including air and surface soil temperature ( $T_{\mathrm{a}}$ and $T_{\mathrm{s}}$ ), relative humidity $(h)$, wind speed $(v)$, and solar radiation $\left(R_{1}\right)$. The maximum differences in $T_{\mathrm{a}}, T_{\mathrm{s}}, h, R_{\mathrm{l}}$, and $v$ recorded over 40 sampling days were $2.7^{\circ} \mathrm{C}, 5.9^{\circ} \mathrm{C}, 7.6 \%, 0.8 \mathrm{~kW} \mathrm{~m}^{-2}$, and $0.5 \mathrm{~m} \mathrm{~s}^{-1}$, respectively; clear diurnal patterns were detected for all 5 variables with greater variability during the day than at night; changes in temperatures and relative humidity over time appeared to be more predictable than those in wind speed and solar radiation. Local weather condition was linearly related to the above variability and, therefore, can be used as a reliable independent variable to predict a forest's microclimate and variability. Results concluded in this study are essential in providing microclimatic perspective in evaluating silvicultural alternatives for the region in creation of old-growth-like forest structure.
\end{abstract}

KEY WORDS: Microclimate - Old growth · Variability · Douglas fir

\section{INTRODUCTION}

In recent years the dramatic loss of old-growth forests and their associated ecological, economic, and social values worldwide has attracted special attention both among the public and in the scientific community. Old-growth forests are valuable for providing unique wildlife habitat and high quality timber, maintaining overall ecosystem health, and offering great recreational and educational opportunities for people. Remnant stands of old-growth forests are critical for understanding relations between natural disturbances and ecosystem structure. This knowledge will be crucial in developing silviculture alternatives within overall ecosystem conservation (Barnes 1989, Perry \& Maghembe 1989, Runkle 1991, Franklin 1992, 1993, Swanson \& Franklin 1992).

\footnotetext{
•E-mail: jiq@mtu.edu
}

Extensive studies of the structure and function of old-growth forests were pioneered in the Pacific Northwest of North America as part of the International Biological Program (IBP) in the 1970s and have continued since the 1980 s with the Long-Term Ecological Research (LTER) program. These studies have significantly influenced and stimulated old-growth research nationally and globally (Sollins et al. 1980, Parker 1989, Maser 1994, Tyrrell \& Crow 1994). Previous studies have demonstrated that old-growth Douglas-fir [Pseudotsuga menziesii (Mirb.) Frankco] forests are highly complex in structure. For example, these forests range widely in species, age, and size; snags and down logs are common, and high levels of spatial heterogeneity characterize canopy gaps, understory vegetation, and wildlife species. Forest function is equally complex, as indicated by high-quality wildlife habitats, high soil productivity, and ecosystem resiliency (Franklin et al. 1981, Franklin \& Spies 
1984). Protection of extant old-growth forest and efforts to create old-growth-like stands have become a major concern in the Pacific Northwest (FEMAT 1993) and elsewhere (Frelich et al. 1993, Mladenoff et al. 1993, O'Hara et al. 1994). For example, current practices of uneven-aged management through group harvests, mimicking windthrows to create canopy gaps, green-tree retention with various longer rotations (Johnson et al. 1991, FEMAT 1993), and aggregating harvest activities at landscape levels are all aimed at this goal (DeBell \& Curtis 1993, Swanson \& Franklin 1992).

Current and previous studies have attempted to define old-growth conifer forest of the Pacific Northwest (OGDTG 1986, Barnes 1989) and to quantify features of its structure, function, and dynamics (Franklin \& Waring 1980, Franklin et al. 1981, Franklin \& Spies 1984, Spies \& Franklin 1988, Bradshaw \& Spies 1992). These features include the roles of coarse woody debris (Harmon et al. 1986, Maser et al. 1988), the historical influence of natural disturbances (Hemstrom \& Franklin 1982, Runckle 1985, Agee 1991), the spatial characteristics of old growth at landscape levels (Ripple et al. 1991, Spies et al. 1994, Wallin et al. 1994), and wildlife habitat and biological diversity (Hansen et al. 1991, Ruggiero et al. 1991) In contrast, very little is known about the physical environment of old growth, such as microclimate and $\mathrm{CO}_{2}$ distribution, or the relation of the environment to the structural characteristics of these forests. Current data on microclimate conditions influenced by forest structure in old-growth Douglas-fir forest are essentially limited to results from long-term monitoring at a single station (Bierlmaier \& McKee 1989), although such data are also scattered within reports of other ecological investigations (e.g. Edmonds 1980, Franklin \& Waring 1980, Chen et al. 1993b, 1995).

Studies of microclimate variation under old-growth canopies are critically important in understanding overall ecosystem structure and function. This is true because microclimate directly influences, or is correlated to most ecological and physiological processes (e.g. germination, abundance, and distribution of understory vegetation, decomposition) (Waring \& Schlesinger 1985). Our working hypothesis is that significant microclimatic variability within the oldgrowth forests exists because forest canopies are vertically complex and horizontally heterogeneous. Logically, these structural variations will produce a highly variable microclimate compared with that of early successional stands characterized by continuous or single-layer canopies. For example, the amounts of and changes in solar radiation, air and surface soil temperature, and moisture within canopy gaps clearly differ as a function of canopy continuity (Canham et al. 1990). Furthermore, consideration of relations between canopy structure and forest microclimate is essential in developing, evaluating, and improving adaptive silviculture alternatives like the green-tree retention of 'new forestry' or in overall ecosystem management practices (Franklin 1992), largely because microclimatic changes are the most immediate consequences following the silvicultural manipulations (e.g. light and moisture). Some first-order questions include: (1) how much variation in microclimate exists under the old-growth canopies? (2) are these patterns of variation constant over time? and (3) how do local weather conditions affect these variations over time?

In the Pacific Northwest, scientists are proposing an array of harvesting methods that incorporate techniques like green-tree retention and the creation of canopy gaps. These are intended to produce oldgrowth characteristics and thereby maintain the complex functions of the ecosystems, which in turn would facilitate multiple uses of the forest (Franklin 1992, DeBell \& Curtis 1993). Microclimate and its variation and their relationship to various harvesting alternatives can be useful when making predictions concerning germination and understory vegetation and also when assessing the success of silviculture methods as reflected by microclimate variables at different harvested sites. For example, North et al. (1996) found that species richness in green-tree retention sites is significantly higher than that at clearcuts and adjacent intact mature stands. Consideration of microclimate and microclimatic variability within stands offers potential explanations of their findings, and further information for modification of current silviculture methods towards an ecological management of forest ecosystems.

Early studies examining how forest edges affect microclimate patterns compared the microclimate of old-growth Douglas-fir forest with adjacent landscape elements (Chen et al. 1993b, 1995). An empirical model was developed to predict interior forest temperature based on local weather conditions (Chen et al. 1993a). In the study presented here, the primary objective was to quantify microclimate variability within an old-growth Douglas-fir forest during the growing season to provide the scientific community with first-hand data on the old-growth environment. The variables air and surface soil temperature, relative humidity, shortwave radiation, and wind speed during the growing season were monitored to quantify: (1) the diurnal changes in residuals for each variable $e_{i}(2)$ the diurnal changes in climate variabilities as expressed by their standard deviation during the sampling periods; and (3) the influences of local weather conditions on the above diurnal patterns. 


\section{MATERIALS AND METHODS}

2.1. Data collection. This study was conducted in an old-growth Douglas-fir forest at an elevation of $620 \mathrm{~m}$ in the Trout Creek Hill area of the Wind River Experimental Forest $\left(45^{\circ} 48^{\prime} \mathrm{N}, 121^{\circ} 55^{\prime} \mathrm{W}\right)$, which is part of the Gifford Pinchot National Forest, Washington, USA. The study area is on a gentle $\left(<5^{\circ}\right)$ slope that faces southeast $\left(232^{\circ}\right)$. Dispersed clearcuts and plantations in the 1970s and early 1980s fragmented the forest there, so that it is now best characterized as having a 'checker-board' pattern (Franklin \& Forman 1987). In one of the largest forest patches and in the most continuous patches, we installed weather stations using the centers of the patches in order to minimize edge effects; all stations were at least $250 \mathrm{~m}$ from the nearest clearcut edge or road. The large patch contains canopy gaps of various sizes, due to interactive disturbance events by several major fires in the early part of the century and frequent winds from the Columbia Gorge. Trees found here included western hemlock Tsuga heterophylla (Raf.) Sarg., scattered large Douglas-fir, sparsely distributed Pacific silver fir Abies amabilis Dougl. ex Forbes, Pacific yew Taxus brevifolia Nutt, western red cedar Thuja plicata Donn ex D. Don, and vine maple Acer circinatum Pursh. Major shrubs included various species of Vaccinium, salal Gautheria shallon Pursh, and Oregon grape Berberis nervosa Pursh.

Three $200 \mathrm{~m}$ line transects with random bearings of $140^{\circ}, 45^{\circ}$, and $105^{\circ}$ were laid out $(\mathrm{df}=18)$ in May 1990. Using a random number generator, 6 locations were selected along each transect for installing weather stations. At each location, a mobile tripod holding 1 relative humidity and temperature sensor, 1 anemometer, 3 radiometers, 1 surface soil temperature sensor, and a cooler with data loggers were set up. At a distance of $15 \mathrm{~m}$ from each of the 6 central locations along the transect, 2 additional locations were selected for installing air and surface soil temperature sensors (Fig. 1). This design provided 18 sets of data on air temperature, soil temperature, and light, as well as 6 sets of wind speed and relative humidity data. All of these

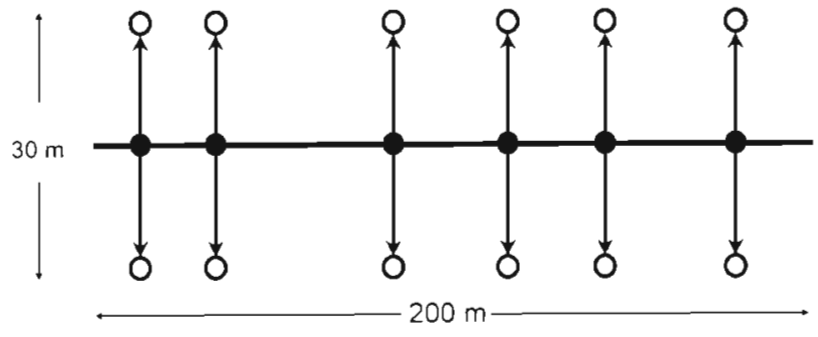

Fig. 1. Experimental design of microclimate sampling along a $200 \mathrm{~m}$ line transect. Six random locations (1) were allocated along the transect to measure air temperature, relative humidity, and wind speed, and 3 locations were allocated for measuring short-wave radiation at $2 \mathrm{~m}$ above the ground and for surface soil temperatures at $5 \mathrm{~cm}$ within the soil. Two additional locations (O) at $15 \mathrm{~m}$ distance from each of the 6 points along the central transect were allocated to sample 2 additional air and surface soil temperatures

readings were obtained during 3 sampling periods: July 2 to August 6, 1990 and August 28 to September 3, 1990 for Transects 1 and 2; and July 7 to August 2, 1992 for Transect 3. A permanent weather station which also recorded all the foregoing variables was installed at the center of an adjacent clearcut to the transects, and these data have been used throughout this paper to characterize 'local' weather conditions.

Air temperature, relative humidity, short-wave radiation, and wind speed sensors were mounted $2 \mathrm{~m}$ above the ground, and surface soil temperature sensors were placed in the soil at depths of $5 \mathrm{~cm}$. Measurements of each variable were recorded every $15 \mathrm{~s}$ and averaged over 30 min intervals (Table 1). Over the 3 sampling periods, conditions were sampled on a total of 41 days, 35 of them complete days from 00:00 to 24:00 h. These 35 include Days 1 to 10 for Transect 1, Days 11 to 15 for Transect 2, and Days 16 to 35 for Transect 3 (see Fig. 3a)

2.2. Data analysis. To quantify the absolute differences of microclimate variables, a minimum value at any given time was used as a reference to subtract from other repeated measurements over the entire $41 \mathrm{~d}$ of the 3 sampling periods. Using air temperature as an example, absolute difference in air temperature

Table 1. Descriptions of meteorological instruments used in this study

\begin{tabular}{|lll|}
\hline Sensor & Producer & Measure \\
\hline 207 Phys-Chem temperature \& RH probe & Campbell Scientific Inc, Logan, UT & $T_{\mathrm{d}}\left({ }^{\circ} \mathrm{C}\right)$ and $h(\%)$ \\
24 gauge E type thermocouples & Custom-built & $T_{\mathrm{a}}\left({ }^{\circ} \mathrm{C}\right)$ \\
24 gauge T type thermocouples & Custom-built & $T_{\mathrm{s}}\left(\left(^{\circ} \mathrm{C}\right)\right.$ \\
12102 Gill 3 Cup anemometer & RM Youngs Company, Traverse City, MI & $V\left(\mathrm{~m} \mathrm{~s}^{-1}\right)$ \\
Li-200s silicon pyranometer & LI-COR, Lincoln, NE & $R_{\mathrm{t}}\left(\mathrm{kW} \mathrm{m}^{-2}\right)$ \\
$21 X$ Datalogger & Campbell Scientific Inc., Logan, UT & Data accessories \\
PC208 & Datalogger Support Software & Programming and communication \\
\hline
\end{tabular}


$\left[\Delta T_{\mathrm{a}}(I)\right]$ at a given time was computed as:

$$
\Delta T_{\mathrm{a}}(I)=T_{\mathrm{a}}(I)-\operatorname{MIN}\left[T_{\mathrm{a}}(1,2, \ldots, 18)\right]
$$

where $T_{\mathrm{a}}(I)$ is the air temperature recorded at station $I(I=1,2, \ldots, 18)$. The variability of $\Delta T_{\mathrm{d}}(I)$ is expressed as standard deviation $\left[\operatorname{SD}\left(\Delta T_{\mathrm{a}}\right)\right]$ at a given time of day over the 35 complete $(24 \mathrm{~h}$ ) sampling days. These diurnal changes in $\operatorname{SD}\left(\Delta T_{\mathrm{a}}\right)$ over the sampling period $(\mathrm{n}=35$ ) were summarized by their averages, minimums, maximums, and $95 \%$ confidence intervals. The maximum values were used to compute absolute differences in relative humidity. A zero value (i.e. the minimum) was used to compute short-wave radiation and wind speed differences through the above analysis.

Local weather conditions strongly influ-

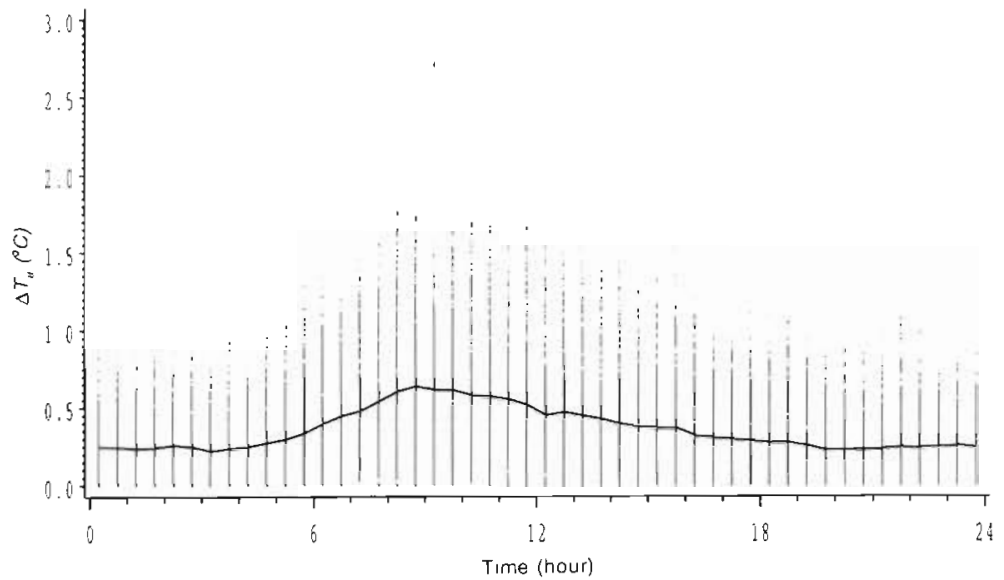

Fig. 2. Absolute differences in air temperature $\left(\Delta T_{a},{ }^{\circ} \mathrm{C}\right)$ in an old-growth Douglas-fir forest, based on $41 \mathrm{~d}$ of field sampling during the growing seasons of 1990 and 1992. The solid line represents the mean values of these differences ence microclimate and its variability under forest canopies (Oke 1987) and they can be used as independent variables for predicting forest microclimate (Chen et al. 1993a). In this study, we used daily maximum $\left[\operatorname{MAX}\left(T_{\mathrm{a}}\right)\right]$ and difference $\left[\operatorname{DIFF}\left(T_{\mathrm{a}}\right)\right]$ (i.e. maximum - minimum) recorded at the center of the clearcut as the major variables describing local weather conditions. The influences of these derived variables on each microclimate variable was examined by plotting the diurnal changes of $\operatorname{SD}\left(\Delta T_{\mathrm{a}}\right)$ against the corresponding $\operatorname{MAX}\left(T_{\mathrm{a}}\right)$ and $\operatorname{DIFF}\left(T_{\mathrm{a}}\right)$.

\section{RESULTS}

\subsection{Air temperature $\left(T_{a}\right)$}

Air temperature difference $\left(\Delta T_{a}\right)$ under the old-growth forest canopy varied an average of $0.25^{\circ} \mathrm{C}$ at night (before sunrise) and $0.6^{\circ} \mathrm{C}$ during the day and ranged as high as 1.5 to $2.7^{\circ} \mathrm{C}$ (Fig. 2). The increasing trend in $\Delta T_{\text {a }}$ began at 06:00 $\mathrm{h}$, peaked in mid-morning at 09:00$10: 00 \mathrm{~h}$, then gradually decreased to its night level (after 17:00 h). Based on the 35 sampling days, there appeared to be great variability among these left-skewed, bellshaped diurnal patterns (Fig. 3a), including a typical leftskewed shape (Days 1, 3, 6, 7, 8, 14, 15, 17, 19, 20, 22, 31, 32 , and 34), a multi-peaked shape (Days 2, 4, 23, 24, 30 , and 33), and a flat shape (Days 26, 27, and 28). Furthermore, small-scale variability in $\operatorname{SD}\left(\Delta T_{a}\right)$ was higher in the daytime than at night (Fig. 3a).

A box plot of $\mathrm{SD}\left(\Delta T_{a}\right)$ over the 35 sampling days indicates that the small-scale variability of air temperature was caused by extreme high values (Fig. 3). Although diurnal changes in minimum, average, and $95 \%$ confidence intervals of $\operatorname{SD}\left(\triangle T_{\mathrm{a}}\right)$ were rather stable, indicat- ing a high predictive capability, maximum values were more erratic (Fig. 3b). Higher variation in $\operatorname{SD}\left(\Delta T_{\mathrm{a}}\right.$ ) at about $02: 00 \mathrm{~h}$ was primarily caused by 3 high values on Days 23, 24, and 33 (Fig. 3a).

Local weather conditions during the sampling periods (Fig. 4) contributed significantly to the diurnal patterns in $\mathrm{SD}\left(\Delta T_{\mathrm{a}}\right)$. Under cooler and stable conditionsthat is, low $\operatorname{DIFF}\left(T_{\alpha}\right)$-diurnal changes in $\operatorname{SD}\left(\Delta T_{\mathrm{a}}\right)$ were less obvious, but they showed a linear increase with $\operatorname{MAX}\left(T_{a}\right)$ and $\operatorname{DIFF}\left(T_{a}\right)$, especially during the daytime. Erratic values causing larger variability on $\operatorname{SD}\left(\Delta T_{\mathrm{a}}\right)$ occurred on days with higher $\operatorname{MAX}\left(T_{\mathrm{a}}\right)$ and $\operatorname{DIFF}\left(T_{\mathrm{a}}\right)$ values.

\subsection{Surface soil temperature $\left(T_{\mathrm{s}}\right)$}

Changes in surface soil temperature difference $\left(\Delta T_{s}\right)$ existed, and several major features are apparent when compared with diurnal changes in $\Delta T_{\mathrm{a}}:$ (1) average $\Delta T_{\mathrm{s}}$ during both daytime $\left(\approx 1.15^{\circ} \mathrm{C}\right)$ and nighttime $\left(\approx 1^{\circ} \mathrm{C}\right)$ hours were much higher than the average values of $\Delta T_{\mathrm{a}}$; (2) the maximum $\Delta T_{\mathrm{s}}$ was as high as $3^{\circ} \mathrm{C}$ at night and $5.9^{\circ} \mathrm{C}$ in the day; (3) $\Delta T_{\mathrm{s}}$ peaked later than $\Delta T_{\mathrm{a}}$ at about 11:00 h, and the peak lasted for 5 to $6 \mathrm{~h}$, to 16:00 $\mathrm{h}$; and (4) small-scale fluctuation was absent or very minor (Fig. 5).

Diurnal patterns of $\mathrm{SD}\left(\Delta T_{\mathrm{s}}\right)$ over the 35 sampling days were also different from $\operatorname{SD}\left(\Delta T_{\mathrm{a}}\right)$ (Fig. 6a). These patterns typically showed a single peak centered around 12:00 h (Days 16-25 and 29-35), twin peaks during the daytime (Days 1-8), a trough shape during the middle of the day (Days 12-14), or a flat shape (i.e. no diurnal pattern, Days 11 and 26-28). Statistics over the 35 days also suggest that these diurnal changes in $\operatorname{SD}\left(\triangle T_{\mathrm{s}}\right)$ were more 

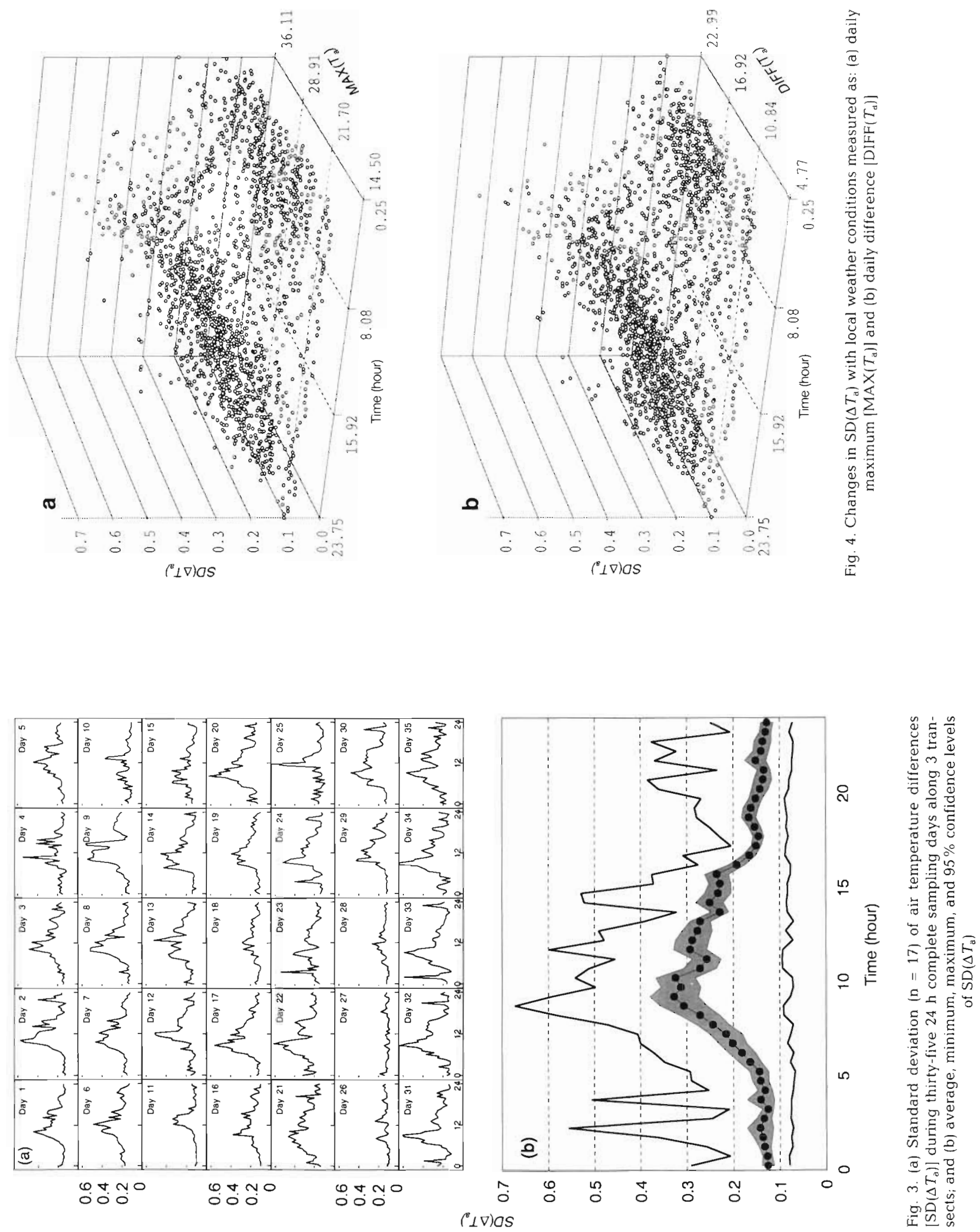


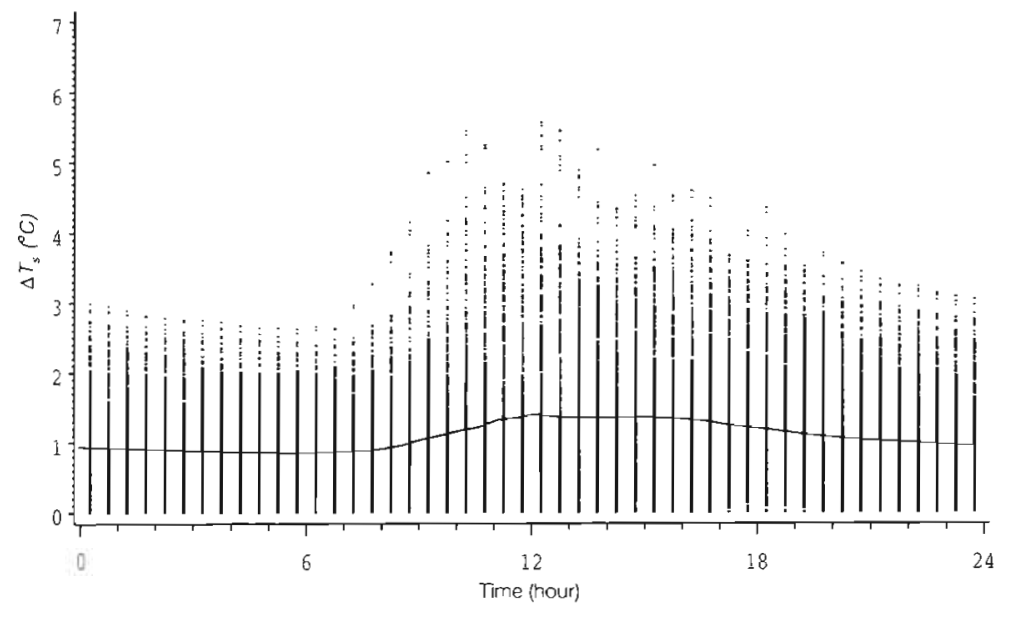

Fig. 5. Absolute differences in surface soil temperature $\left(\Delta T_{\mathrm{s}},{ }^{\circ} \mathrm{C}\right)$ in an oldgrowth Douglas-fir forest based on $41 \mathrm{~d}$ of field sampling during the growing seasons of 1990 and 1992 . The solid line represents the mean values of these differences

stable and predictable than the changes in $\operatorname{SD}\left(\Delta T_{\mathrm{a}}\right)$ (see $95 \%$ confidence intervals, Fig. 6b).

Influences of 'local weather conditions' on the diurnal changes in $\mathrm{SD}\left(\Delta T_{\mathrm{s}}\right)$ were also similar to $\operatorname{SD}\left(\Delta T_{\mathrm{a}}\right)$ (Fig. 7a). However, the relation between $\operatorname{SD}\left(\Delta T_{\mathrm{s}}\right)$ and $\operatorname{MAX}\left(T_{5}\right)$ was closer to exponential, while the relation between $\operatorname{SD}\left(\Delta T_{\mathrm{s}}\right)$ and $\operatorname{DIFF}\left(T_{\mathrm{s}}\right)$ was linear (Fig. 7b). Furthermore, the linear nighttime relation between $\operatorname{SD}\left(\Delta T_{s}\right)$ and $\operatorname{DIFF}\left(T_{s}\right)$ lasted until noon $(12: 00 \mathrm{~h})$, whereas the non-linear nighttime relation between $\mathrm{SD}\left(\Delta T_{\mathrm{s}}\right)$ and $\operatorname{DIFF}\left(T_{s}\right)$ switched earlier, at 10:00 h.

\subsection{Relative humidity $(h)$}

Average diurnal changes in relative humidity $(\Delta h)$ showed lower values at night $(0.6 \%)$ and higher values during the day $(1.5 \%)$, with maximum values of 3.8 and $7.6 \%$, respectively (Fig. 8 ). Three peaks during the daytime were recorded at about 09:45, 14:15, and $18: 15$ h. Small-scale variation in $\Delta h$ at night was smaller than during the day.

The triple-peak phenomenon was caused primarily by different diurnal patterns during the sampling periods. Based on Fig. 9a, it is clear that $\operatorname{SD}(\Delta h)$ at night was low during most sampling days and peaked in the late morning $(10: 00$ to $12: 00 \mathrm{~h})$. A twin-peak pattern was common (Days 3, 8-9, 13-15, 23, 26, 30, and 31-35), but other patterns over $24 \mathrm{~h}$ were also recorded; for instance $\operatorname{SD}(\Delta h)$ values were either consistently high (Days 4 and 21-24) or low (Days 11 and 27). Like diurnal changes in $\operatorname{SD}\left(\Delta T_{\mathrm{a}}\right)$, average changes in $\mathrm{SD}(\Delta h)$ were highly predictable (see their $95 \%$ confidence intervals in Fig. 9b), with larger $\mathrm{SD}(\Delta h)$ values seemingly the major causes of reduced predictability.
Linear relationships existed between $\mathrm{SD}(\Delta h)$ and local weather conditions. Basically, variability in $\Delta h$ was much higher during the daytime than during night hours, and it increased with the daily low extreme $[\operatorname{MIN}(\Delta h)]$ and with the differences $[\operatorname{DIFF}(\Delta h)]$ (Fig. 10). Unpredictable values for $\mathrm{SD}(\Delta h)$ based on its relation to $\operatorname{DIFF}(\Delta h)$ or MIN $(\Delta h)$ occurred mostly from $12: 00$ to $24: 00 \mathrm{~h}$.

\subsection{Short-wave radiation $\left(R_{t}\right)$}

Variation in short-wave radiation $\left(\Delta R_{t}\right.$,

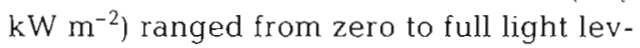
els, and it averaged from about 0.04 to 0.06 $\mathrm{kW} \mathrm{m} \mathrm{m}^{-2}$. Residuals from the means were skewed toward high light levels (Fig. 11). Our data indicate that the diurnal pattern on clear days (e.g. Days 1 to 9) in the open, clearcut area may be identical with the light level at any given time beneath the canopy. However, at 2 periods during the day $\left(09: 15-10: 15 h\right.$ and 12:15-14:15) $\Delta R_{\mathrm{t}}$ reached higher values.

The twin- or triple-peak phenomenon was common over the 35 sampling days (Days 1-3,5-9, and 20-30) (Fig. 12a). Based on Fig. 12a, it is evident that Days 10-15 and 26-28 had a flat diurnal pattern (i.e. cloudy skies) and this may help in interpreting the small and stable variations in temperature and moisture (Figs. 3a, $6 \mathrm{a} \&$ 9a). Three peaks in $\mathrm{SD}\left(\Delta R_{\mathrm{t}}\right)$ were caused by a high light level at about 09:45 h and 12:45 h during the sampling of Transects 1 and 2 and at 14:15 h during the sampling of Transect 3 (Fig. 12a). In short, 95\% confidence intervals were narrower (i.e. more predictable) with the extreme high values (Fig. 12b)

The variation in short-wave radiation $\left[\operatorname{SD}\left(\Delta R_{\mathrm{t}}\right)\right]$ bore a linear relation to the light level in the open area $\left(R_{\mathrm{to}}\right)$ (Fig, 13). Higher variations seemed to occur around noontime, with the highest values immediately before or after 12:00 $\mathrm{h}$. The linear relation between $\mathrm{SD}\left(\Delta R_{\mathrm{t}}\right)$ and $R_{\mathrm{to}}$ was stronger in the early morning and late afternoon than around noontime. The correlation between $\operatorname{SD}\left(\Delta R_{\mathrm{t}}\right)$ and $R_{\text {to }}$ decreased as $R_{\text {to }}$ increased.

\subsection{Wind speed ( $v)$}

The diurnal changes in wind speed $\left(\Delta v, \mathrm{~m} \mathrm{~s}^{-1}\right)$ appeared high during the day (09:00-16:00 h) and low at night (Fig. 14). However, this diurnal pattern was accompanied by larger values over the $24 \mathrm{~h}$, except for a short period between 04:45 and 06:45 h. The extreme 

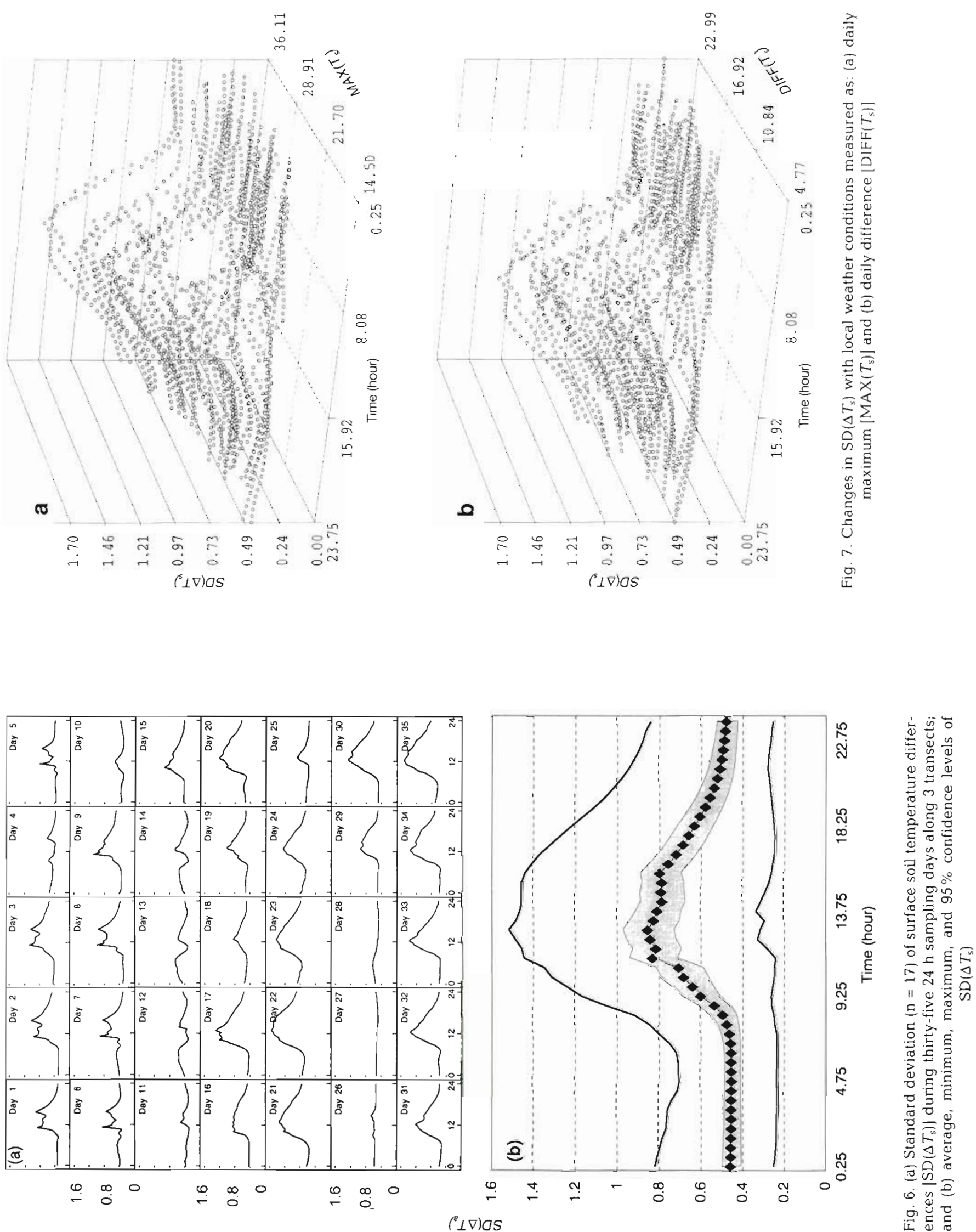


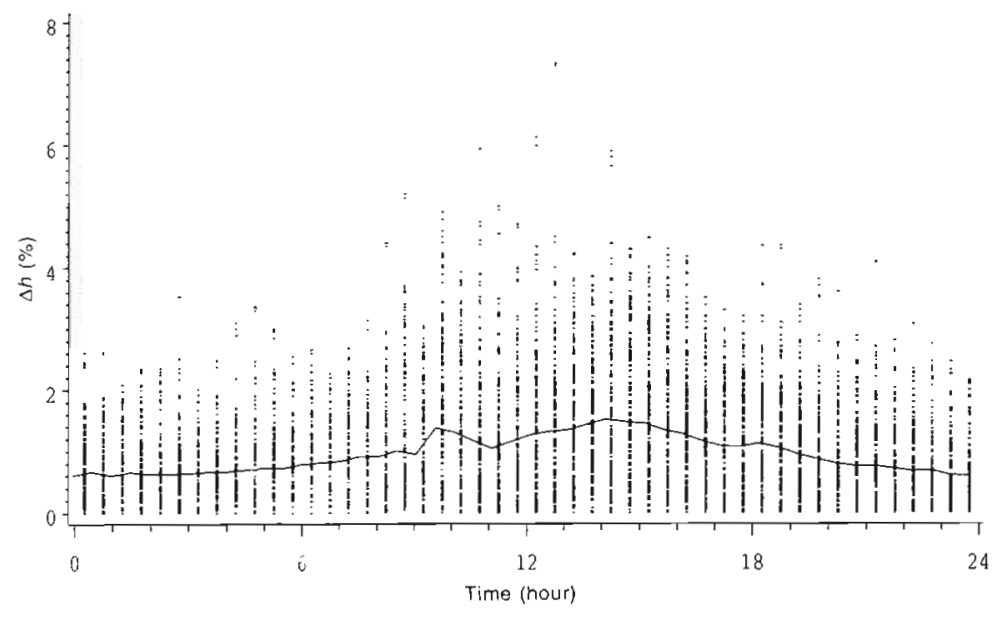

Fig. 8. Absolute differences in relative humidity $(\Delta h, \%)$ in an old-growth Douglas-fir forest based on $41 \mathrm{~d}$ field sampling during the growing season of 1990 and 1992. The solid line represents the mean values of these differences

high values in $\Delta v$ were found for 3 periods: 01:45$03: 45,10: 15-14: 15$, and 17:25-22:15 h. Although a typical diurnal pattern for $\Delta v$ was found on Days $1,5,6-7$, 9,18 , and 24 , many other patterns also existed, as expressed by $\mathrm{SD}(\Delta v)$. These included patterns of calm at night and wind during the day (Days 2-5, 11-17. $19-22,25-26$, and 29-35), staying either consistently high (Day 23) or low (Days 10, 12, and 27), (Fig. 15a) throughout the $24 \mathrm{~h}$. Basic statistics for $\operatorname{SD}(\Delta v)$ suggest that wind speed variation inside the forest was highly predictable but strongly influenced by extreme values (Fig. 15b).

Diurnal patterns with low variation around 06:00 h were recorded (Fig. 16). Unlike other microclimate variables, the diurnal changes in $\mathrm{SD}(\Delta v)$ correlate only weakly with the external wind speed (i.e. wind speed in the clearcut). High $\operatorname{SD}(\Delta v)$ values occurred at all times of day, depending on the different external wind speeds (Fig. 16): probably this is because the maximum external speed during the sampling periods was only $2 \mathrm{~m} \mathrm{~s}^{-1}$.

\section{DISCUSSION}

Spatial and temporal differences in all microclimate variables under old-growth forest canopies were recorded during 3 sampling periods of 2 growing seasons. In general, microclimate variation within the forest was higher during the day than at night, although different diurnal patterns existed among the variables. The times at which extreme values occurred during the $24 \mathrm{~h}$ sampling periods also differed among the variables; variation in air temperature, relative humidity, and surface soil temperature occurred before, around, and after noon, respectively (Figs. 3, 6, \& 9). For the diurnal changes in relative humidity, solar radiation, and wind speed, clear multiple peaks were found (Figs. 8, 11 \& 14). Variability at smaller temporal scales (i.e. $30 \mathrm{~min}$ to $2 \mathrm{~h}$ ) was greater for air temperature, relative humidity, and wind speed. Previous studies stated that variability in solar radiation under forest canopies should range from zero to full sunlight (Chen et al. 1993b, Larsen \& Kershaw 1996). However, our data indicate very little variation. This is because they were averaged over $30 \mathrm{~min}$. In old-growth Douglas-fir forest, the duration of sun flecks ranges from 8 to $10 \mathrm{~min}$ (Canham et al 1990). For that reason, both the small scale variation and the absolute variability in this study was obscured through averaging, i.e. we lose details or noise at broader scales. Similarly, microclimatic variability at broader temporal scales, such as daily, seasonal, and yearly, can not be quantified in this study.

Better understanding of microclimatic variability requires spatial information about the forest structure-especially canopy structure-in the vicinity of the sampling locations. Strong relations exist between forest microclimate and vegetation characteristics such as canopy coverage and layers, leaf area index, coverage by understory shrubs and herbs, and litter depth (Hungerford \& Babitt 1987, Chen et al. 1993b). For example, a study of solar radiation within and around circular gaps found that the greatest extremes of microclimate variation were in the northern part of canopy gaps rather than in the center (Canham et al. 1990). Our results showing a larger variation in soil moisture and solar radiation were probably also caused by this small-scale heterogeneity of forest structure (also see Hungerford \& Babitt 1987, Chen et al. 1993b). Our original objective in this study was to characterize climate variability. However a lack of information about the spatial locations of weather stations and corresponding canopy structure made it impossible to explain this microclimate variability mechanistically. In future studies, field measurements of spatial information and relationships should not be ignored.

Empirical studies of forest microclimate variability can also be made using energy budget or more sophisticated turbulence theories (Oke 1987, Lee \& Black 1993). These process-based approaches will provide insight and precise predictions of the effects of forest microclimate at broader scales on differences in vegetation, but they present 3 major difficulties: (1) vegeta- 

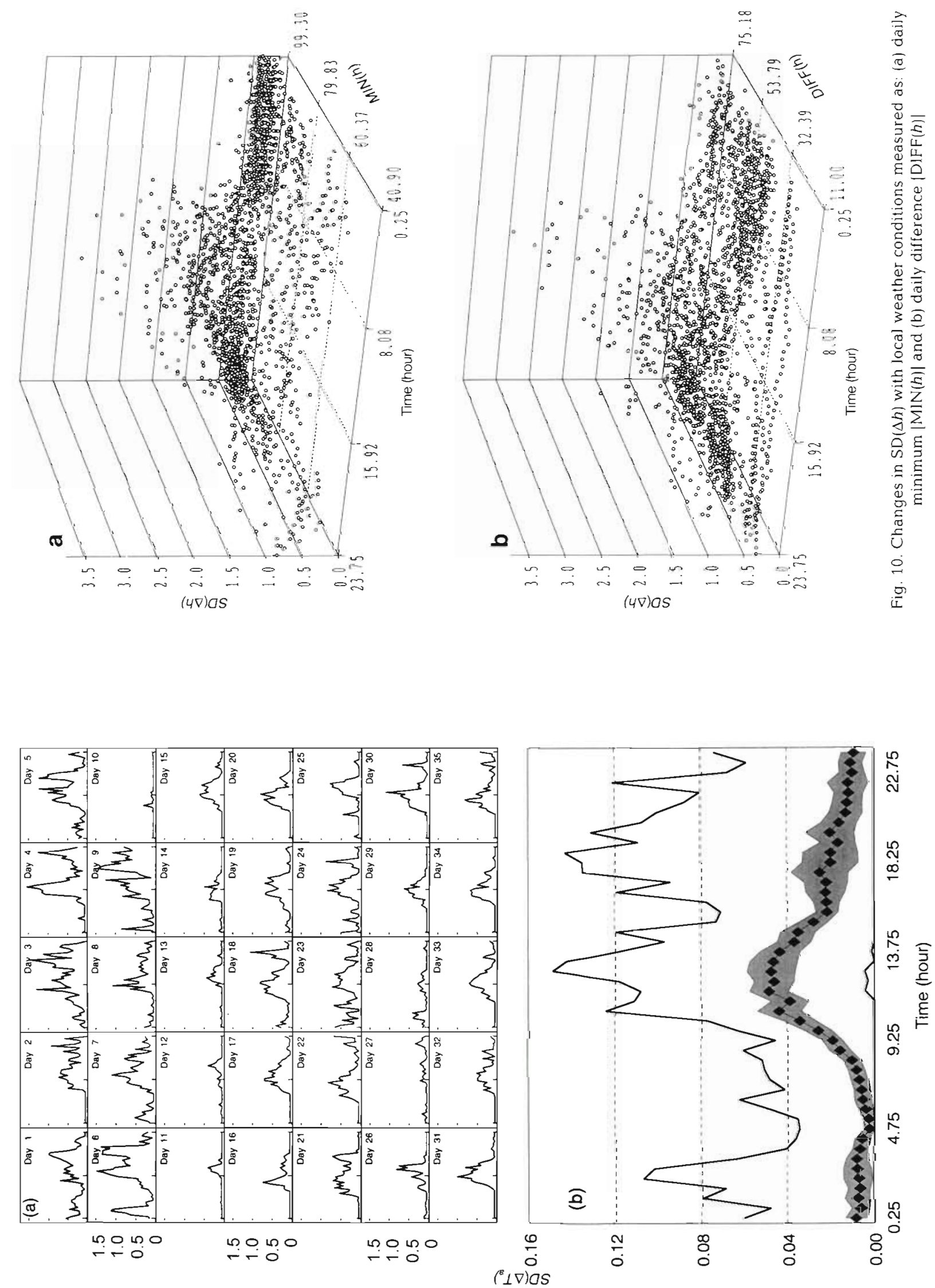

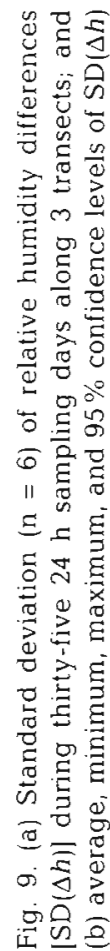



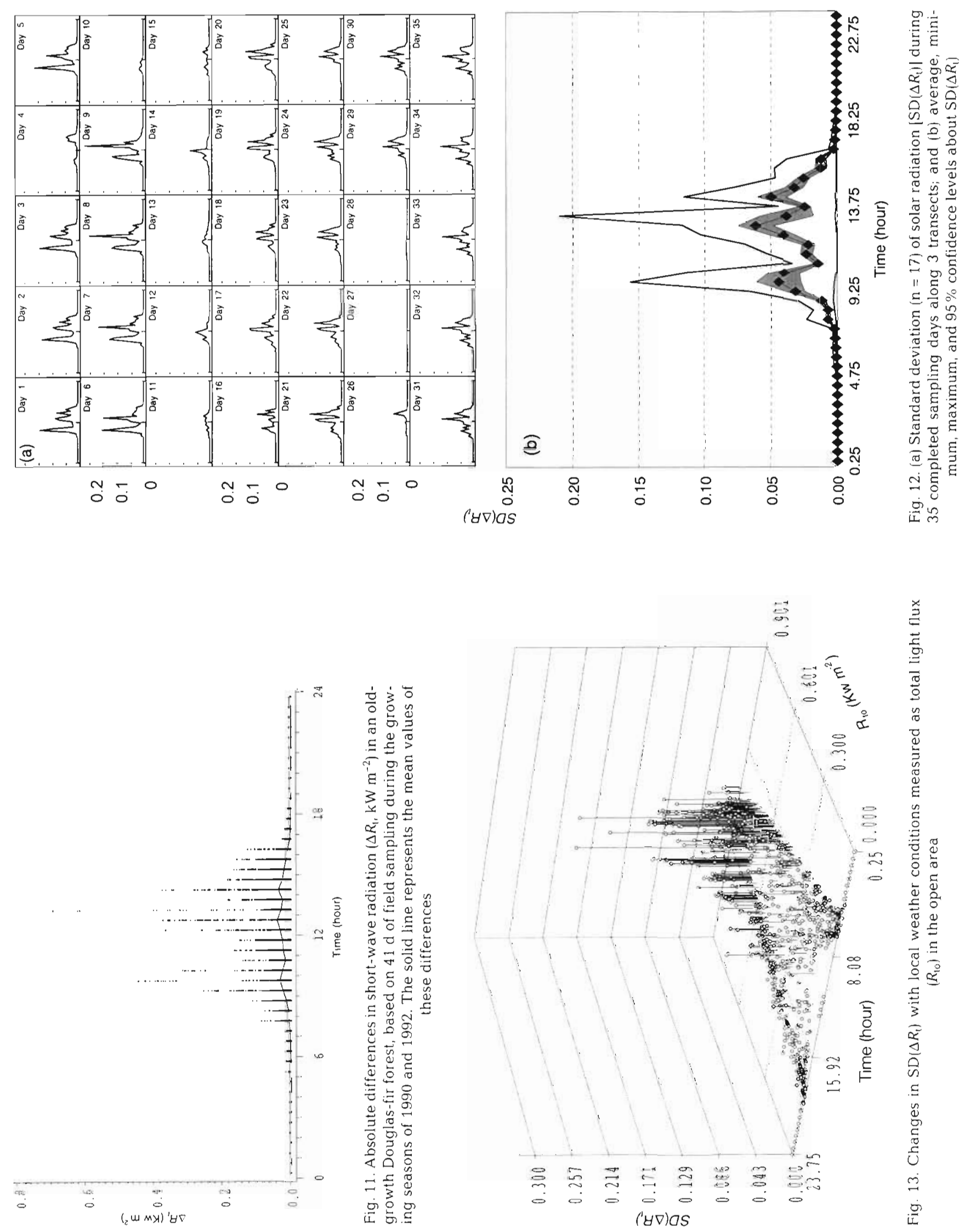

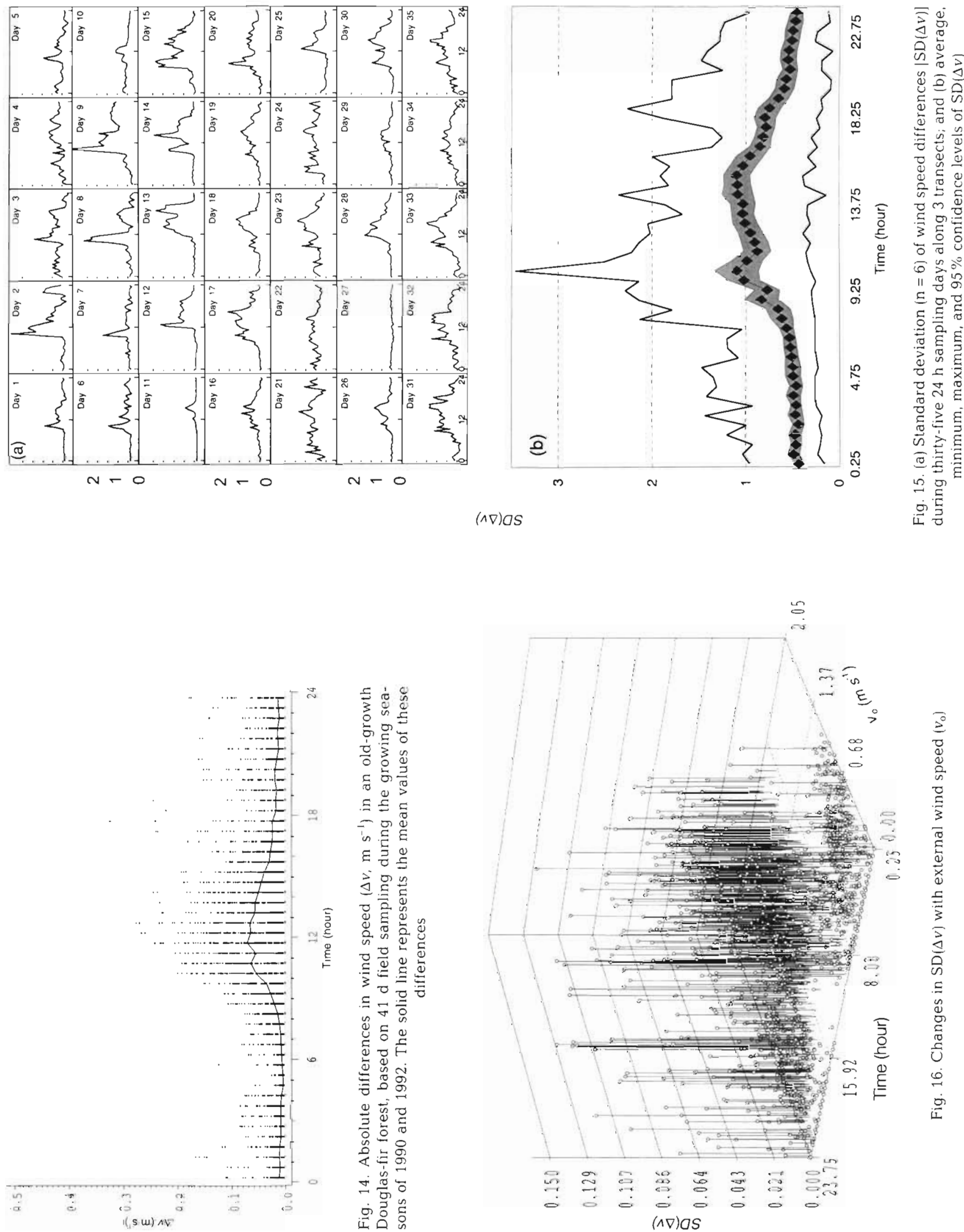
tion structure and spatial heterogeneity are too difficult to sample and quantify, especially in old-growth forests; (2) instruments needed for energy budget or turbulence studies are costly, and, therefore, studies will be limited to a small amount of sampling; and (3) horizontal (or 3-dimensional) transport of energy in an old-growth forest is largely a stochastic process and therefore is almost impossible to quantify. In contrast, the empirical approach used in this study allows quantification and prediction of microclimate patterns based on simple measurements of local weather conditions. Such an economical approach may be more appropriate than other methods of predicting the temporal and spatial variability of forest microclimate, especially at medium (100s of meters) to large (kilometers) scales (Wooster 1989, Kuuseoks et al. in press). Statistical relationships developed using this approach should also help to predict forest microclimate and variability when local weather conditions change. An example of this would be to predict forest microclimate under assumptions of global climate change, using a top-down approach to scale our model output into landscape and stand levels (Meentemeyer \& Box 1987. Giorgi \& Mearns 1991).

Forest microclimate and variability described in this study can be directly used to interpret ecological processes near the ground (e.g. decomposition, regeneration, and development of patchy vegetation). However, the confidence level will decrease when results are extrapolated to predict processes higher than $2 \mathrm{~m}$ above the ground, such as overstory photosynthesis, growth, canopy epiphytes, and wildlife habitat. Research priorities in forest microclimate should seek answers to questions such as: (1) what are the microclimate profiles from the ground to the top of canopies? (2) how do these profiles change across the stand and over different temporal scales? and (3) what are the 3-dimensional patterns and dynamics of microclimate within a stand? Obviously, the development of efficient approaches and techniques, such as the use of a canopy crane, is essential in approaching these questions

Results from this study are critical for evaluating and predicting other ecological processes for developing silvicultural alternatives. It is well documented in the scientific community that ecosystem structure and function are not spatially uniform across a forest stand. The forest floor of old-growth forests is typically characterized by patchy understory vegetation, regeneration mosaics, dynamic and variable sun flecks, etc. (Spies \& Franklin 1988, Canham et al. 1990). In a recent study on the spatial variation of nitrogen availability, Gross et al. (1995) found that $50 \%$ of variability is contributed at the stand level. Since these characteristics are directly or indirectly related to microclimate, micraclimatic studies need to be included as necessary components in any comprehensive ecosystem research, in order to predict quantitatively these variabilities. In management, numerous studies (Ghuman \& Lal 1987, Hungerford \& Babitt 1987, Chen et al. 1993b) have suggested that microclimate and its variability are directly related and can be predicted based on overstory structure. Therefore, assessment and development of alternative silvicultural treatments are possible based on such canopy/microclimate-process relationships. However, we must also conclude that results included in this study are based on field data collected in an old-growth Douglas-fir forest and, therefore, can not be extrapolated to young, mature, or other oldgrowth forests.

\section{CONCLUSIONS}

Clear diurnal changes in microclimate variability were monitored over the growing season beneath oldgrowth canopies. The maximum differences for $T_{a}, T_{s}$, $h, R_{t}$, and $v$ were $2.7^{\circ} \mathrm{C}, 5.9^{\circ} \mathrm{C}, 7.6 \%, 0.8 \mathrm{~kW} \mathrm{~m}{ }^{2}$, and $0.5 \mathrm{~m} \mathrm{~s}^{-1}$, respectively.

Microclimate variation during the daytime is higher than at night. Lower variability usually occurs before sunrise and higher variability occurs between 09:00 and 16:00 h. Stronger small-scale variabilities in $T_{a}, h$, and $v$ were recorded

Local weather conditions have a strong influence on the diurnal changes of all microclimate variables. Higher variability tends to be recorded on days with high extremes (MAX), daily differences (DIFF), and under partly cloudy skies.

Acknowledgements. We thank Dr Tom Spies for his original ideas and discussion for field design, and Limin Dai for his assistance in collecting field data. Ruth Kirt, Sari Saunders, and 2 anonymous reviewers provided constructive comments on the early manuscript. Financial support was provided to Jerry Franklin (PNW-90342) at the University of Washington and to Jiquan Chen (PNW-930901) at the Michigan Technological University (MTU) by the Forest Service New Perspective Program and also by the McIntire-Stennis Funds at MTU

\section{LITERATURE CITED}

Agee J (1991) Fire history of Douglas-fir forests in the Pacific Northwest. In: Ruggiero LF (coord) Wildlife and vegetation of unmanaged Douglas-fir forests. USDA For Serv Gen Tech Rep PNW-GTR-285. USDA Forest Service, Portland, $O R, p 25-33$

Barnes BV (1989) Old-growth forests of the northern Lake Sates: a landscape ecosystem perspective. Nat Areas J $9(1): 45-57$

Bierlmaier FA, McKee A (1989) Climatic summaries and documentation for the primary meteorological stations, H. J Andrews Experimental Forest, 1972-1984. USDA For Serv Gen Tech Rep, PNW-GTR-242. USDA Forest Service. Portland, $O R$ 
Bradshaw GA, Spies TA (1992) Characterizing canopy gap structure in forests using wavelet analysis. J Ecol 80: $205-215$

Canham CD, Denslow JS, Platt WJ, Runkle JR, Spies TA, White PS (1990) Light regimes beneath closed canopies and tree-fall gaps in temperate and tropical forests. Can J For Res 20:620-631

Chen J, Franklin JF, Spies TA (1993a) An empirical model for predictıng diurnal air-temperature gradients from edge into old-growth Douglas-fir forest. Ecol Model 67:179-198

Chen J, Franklin JF, Spies TA (1993b) Contrasting microclimates among clearcut, edge, and interior of old-growth Douglas-fir forest. Agric For Metorol 63:219-237

Chen J, Franklin JF, Spies TA (1995) Growing-season microclimatic gradients from clearcut edges into old-growth Douglas-fir forests. Ecol Appl 5(1):74-86

DeBell DS, Curtis RO (1993) Silviculture and new forestry in the Pacific Northwest. J For 91(12):25-30

Edmonds RL (1980) Litter decomposition and nutrient release in Douglas-fir, red cedar, western hemlock, and Pacific silver fir ecosystems in western Washington. Can $\mathrm{J}$ For Res 10(3):327-337

FEMAT (Forest Ecosystem Assessment Team) (1993) Forest ecosystem management: an ecological, economic, and social assessment. USDA Forest Service, Portland, OR

Franklin JF (1992) Scientific basis for new perspectives in forest and streams. In: Naiman RJ (ed) Watershed management: balancing sustainability and environmental change. Springer-Verlag, New York, p 25-72

Franklin JF (1993) Lessons from old growth: fueling controversy and providing direction. $J$ For 91(12):10-13

Franklin JF, Cromack K Jr, Denison W, Mckee A, Maser C, Sedell J, Swanson F, Juday G (1981) Ecological characteristics of old-growth Douglas-fir forests. USDA For Serv Gen Tech Rep PNW-118. USDA Forest Service, Portland, OR

Franklin JF, Forman RTT (1984) Creating landscape patterns by forest cutting: ecological consequences and principles. Landscape Ecol 1(1):5-18

Franklin JF, Spies TA (1984) Characteristics of old-growth Douglas-fir forests. In: Proceedings of the 1983 National Convention, October 16-20,1983, Portland, OR. Society of American Foresters, Washington, DC, p 328-334

Franklin JF, Waring RH (1980) Distinctive features of the northwestern coniferous forest. In: Waring $\mathrm{RH}$ (ed) Proc Annu Bio Colloq, Oreg State Univ Press 40:59-86

Frelich LE, Calcote RR, Davis MB, Pastor J (1993) Patch formation and maintenance in an old-growth hemlock-hardwood forest. Ecology 74(2):513-527

Ghuman BS, Lal R (1987) Effects of partial clearing on microclimate in a humid tropical forest. Agric For Meteorol 40: $17-29$

Giorgı F, Mearns LO (1991) Approaches to the simulation of regional climate change: a review. Rev Geophys 29(2): 191-216

Gross KL, Pregitzer KS, Burton A.J (1995) Spatial variation in nitrogen availability in tree successional plant communities. J Ecol 83:357-367

Hansen AJ, Spies TA, Swanson FD, Ohmann JL (1991) Conserving biodiversity in managed forests. BioSci 41: $382-392$

Harmon ME, Franklin JF, Swanson FJ, Sollins S, Gregory SV, Lattin JD, Anderson NH, Cline SP, Aumen NG, Sedell JR, Lienkaemper GW, Cromack K Jr, Cummins KW (1986) Ecology of coarse woody debris in temperate ecosystems. Adv Ecol Res 15:133-302

Hemstrom M, Franklin JF (1982) Fire and other disturbances of the forests in Mount Rainier National Park. Quat Res 18: $32-51$

Hungerford RD, Babitt RE (1987) Overstory removal and residue treatments affect soil surface, air, and soil temperature: implications for seedling survival. USDA For Serv Res Pap, INT-377 USDA Forest Service, Fort Collins, CO

Johnson N, Franklin JF, Thomas JW, Gordon J (1991) Alternatives for management of late-successional forests of the Pacific Northwest. A Report to the US House of Representatives. Washington, DC

Kuuseoks E, Liechty HO, Reed DD, Dong J (in press) Relatıng site-specific weather data to regional monitoring networks: examples along a regional climate gradient in the lake States. For Sci

Lee X, Black TA (1993) Turbulence near the forest floor of an old-growth Douglas-fir stand on a south-facing slope. For Sci 39(2):211-230

Maser C (1994) Sustainable forestry: philosophy, science, and economics. St. Lucie Press, Delray Beach, FL

Maser C, Tarrant RF, Trappe JM, Franklin JF (eds) (1988) From the forest to the sea: a story of fallen trees. USDA For Serv Gen Tech Rep PNW-GTR-229. USDA Forest Service, Portland, OR

Meentemeyer V, Box EO (1987) Scale effects in landscape studies. In: Turner MG (ed) Landscape heterogeneity and disturbance. Ecological Studies 64, Springer-Verlag, New York, p 15-34

Mladenoff DJ, White MA, Pastor J, Crow TA (1993) Comparing spatial pattern in unaltered old-growth and disturbed forest landscapes. Ecol Appl 3(2):294-306

North M, Chen J, Smith G, Krakowiak L, Franklin J (1996) Initial response of understory plant diversity and overstory tree diameter growth to a green tree retention harvest. NW Sci 70(1):24-35

OGDTG (Old-Growth Definition Task Group) (1986) Irterim definitions for old-growth Douglas-fir and mixed-conifer forests in the Pacific Northwest and California. USDA For Serv PNW Res Stn Note PNW-447. USDA Forest Service, Portland, $O R$

O'Hara KL, Seymour RS, Tesch SD, Guldin JM (1994) Silviculture and our changing profession: leadership for shifting paradigms. J For 92(1):8-13

Oke TR (1987) Boundary layer climates. Methuen, New York

Parker J (1989) Old-growth forests of the central hardwood region. Nat Areas J 9:5-11

Perry DA, Maghembe J (1989) Ecosystem concepts and current trends in forest management: time for reappraisal For Ecol Manage 26:123-140

Ripple WJ, Bradshaw GA, Spies TA (1991) Measuring forest landscape patterns in the Cascade Range of Oregon, USA. Biol Conserv 57:73-88

Ruggiero LF, Aubry KB, Carey AB, Huff MH (coords) (1991) Wildlife and vegetation of unmanaged Douglas-fir forests. USDA For Serv Gen Tech Rep PNW-GTR-285. USDA Forest Service, Portland, OR

Runkle JR (1985) Disturbance regimes in temperate forests. In: Pickett STA, White PS (eds) The ecology of natural disturbance and patch dynamics. Academic Press, New York. p $17-33$

Runkle JR (1991) Gap dynamics of old-growth eastern forests management implications. Nat Areas J 11(1):19-25

Sollins P, Grier CC, McCorison FM, Fredriksen RL (1980) The internal element cycles of old-growth Douglas-fir ecosystems in western Oregon. Ecol Monogr 50(3):261-285

Spies TA, Franklin JF (1988) Old growth and forest dynamics in the Douglas-fir region of western Oregon and Washington. Nat Areas J 8(3):190-201 
Spies TA, Ripple WJ, Bradshaw GA (1994) Dynamics and patterns of a managed coniferous forest landscape. Ecol Appl $4(3): 555-568$

Swanson FJ, Franklin JF (1992) New forestry principles from ecosystem analysis of Pacific Northwest forests. Ecol Appl 2(3):262-274

Tyrrell LE, Crow TR (1994) Structural characteristics of oldgrowth hemlock-hardwood forests in relation to age. Ecology $75(2): 370-386$

Editor: V. Meentemeyer, Athens, Georgia, USA
Wallin DO, Swanson FJ, Marks B (1994) Landscape pattern response top changes in pattern generation rules: landuse legacies in forestry. Ecol Appl 4(3):569-580

Waring RH, Schlesinger WH (1985) Forest ecosystems: concepts and management. Academic Press, Orlando

Wooster KM (1989) A geographically-based microclimatological computer model for mountainous terrain with application to the Luquillo Experimental Forests in Puerto Rico. $\mathrm{MSc}$ thesis, State University of New York, Syracuse

Manuscript first received: February 2, 1996 Revised version accepted: April 17, 1996 